\title{
Ali Galip Olayı'nın Milli Mücadele Taraftarı Gazetelerdeki (İrade-i Milliye ve Albayrak) Yankıları
}

\author{
Yrd. Doç. Dr. Selçuk URAL*
}

\section{ÖZET}

İstanbul Hükümeti'nin Mustafa Kemal Paşa'yı tutuklamak ve Milli Mücadele Hareketi'ni ortadan kaldırmak amacıyla planladığ Ali Galip Olayı, Mustafa Kemal Paşa'nın eşsiz siyasî dehası sayesinde Milli Mücadele'nin siyasî zaferi haline dönüş̧ürülmüşü̈r.

Mustafa Kemal Paşa, Ali Galip Olayı'nı Damat Ferit Paşa Hükümeti'ni iktidardan uzaklaştırmak için kullandt. Bunun için kuvvetli ve etkili kamuoyu desteğine ihtiyaç vardı. Bu doğrultuda pek çok vasıta kullanıldı. Bunlardan biri de gazeteler idi. Bu makalede Ali Galip Olayı'nın İrade-i Milliye ve Albayrak gazetelerinde nasıl ele alındığı ve kamuoyuna nasıl yansıtıldı $\breve{g}_{\imath}$ anlatılmaya çalışılmıştır.

Anahtar Kelimeler: Ali Galip, Heyet-i Temsiliye, Sivas Kongresi, Albayrak Gazetesi, Irade-i Milliye Gazetesi

\section{ABSTRACT}

The Reactions to the Ali Galip Event in the Newspapers

\section{(National Will and Scarlet) Supporting the National Struggle}

The Ali Galip Event which was planned by the Istanbul Government aiming at arresting Mustafa Kemal Pasha and eliminating the National Struggle Movement turned into a triumph of the National Struggle through Mustafa Kemal Pasha's unique political genius.

To remove the Damat Ferit Pasha government from power, Mustafa Kemal Pasha made use of the swooping intention on the Sivas Congress. A strong or

\footnotetext{
• Kafkas Üniversitesi, Fen-Edebiyat Fakültesi Tarih Bölümü, Kars/Türkiye.
} 
effective public support was needed for this intention. According the Nation's will and scarlet Newspapers, which were the voice of the National Struggle, were used to fulfill this aim.

Keywords: Ali Galip, Committee of Representation, Sivas Congression, The Scarlet Paper, National Struggle.

Sivas Kongresi, Milli Mücadele Hareketi'nin önemli safhalarından birini oluşturmaktadır. Kongre, Erzurum Kongresi'nde alınan kararları ülke geneline yaymak amaciyla 4 Eylül 1919 'da yapıldi ${ }^{1}$.

Mustafa Kemal Paşa, Samsun'a çıktığı günden itibaren devletin ve milletin içine düştüğü zor durumdan kurtulabilmesi için bir yandan halkı bilinçlendirmeye ve teşkilatlandırmaya çalışırken, diğer yandan da halkın haklarını koruyabilmesi ve dünyaya duyurabilmesi amacıyla bir milli kongre toplanması gerektiğini savunuyordu. Bunun için mülkî ve askerî makamlarla devamlı surette fikir alışverişinde bulundu. Temasları sonucunda mülkî ve askerî makamların da aynen kendisi gibi, merkezi hükümetin üstlendiği sorumluluğu yerine yetirmekten aciz ve bundan dolayı milletin büyük sıkıntı çektiğini düşündüğünü tespit etti ${ }^{2}$. $\mathrm{O}$ zaman milletin kaderiyle ilgili kararları almak üzere milli bir kongre toplanmasından başka bir çare yoktu. Kongrenin ve milli mücadelenin bânisi Mustafa Kemal Paşa, Nutuk'ta kongre hakkındaki düşüncelerini şu cümlelerle ortaya koyuyordu: "18 Haziran 1919 tarihinde Trakya'ya verdiğim direktifte işaret ettiğim bir noktanın, tatbikı zamanı gelmiş bulunuyordu. Hatırınızdadır ki o nokta, Anadolu ve Rumeli teşkilâtı milliyesini tevhid ederek, bir merkezden temsil ve idare eylemek üzere Sivas'ta umumi bir heyeti milliye toplamaktı."3. Mustafa Kemal Paşa, kongre sayesinde “milletin hal ve vaz'ını derpiş etmek ve sada-yı hukukunu cihana işittirmek için her türlü tesir ve murakabeden azade bir heyeti milliyenin..." vücuda getirilmesini planlıyordu ${ }^{4}$.

Sivas Kongresi'nin yapılmasına dair kararın alındığı günlerde, Vilâyât-1 Şarkiyye Müdafaa-i Hukuk-1 Milliye Cemiyeti Erzurum Şubesi de Erzurum'da bölgesel bir kongre yapmak için bir dizi karar alarak, hazırlıklarını süratle tamamlamaktaydı ${ }^{5}$. 15. Kolordu Komutanı Kâzım

' Erzurum Kongresi kararları hakkında geniş bilgi için bkz: Fahrettin Kırzıoğlu, Bütünüyle Erzurum Kongresi, Ankara 1993; Bekir Sitkı Baykal, Erzurum Kongresi İle İlgili Belgeler, Ankara 1969; Dursun Ali Akbulut, Erzurum Kongresi Hakkında Belgeler, Erzurum 1989.

${ }^{2}$ Mustafa Kemal Paşa'nın bu dönem içindeki çalışmaları hakkında geniş bilgi için bkz: Kemal Atatürk, Nutuk, I, İstanbul 1982, s.10-29.

${ }^{3}$ Atatürk, Nutuk, I, s.30.

${ }^{4}$ Atatürk, Nutuk, I, s.31

${ }^{5}$ Cevat Dursunoğlu, Milli Mücadele'de Erzurum, İstanbul 1998, s.43-58; Haluk Selvi, Milli Mücadele'de Erzurum, Ankara 2000, s.101-108. 
Karabekir Paşa, 16 Haziran 1919'da Mustafa Kemal Paşa'ya gönderdiği telgrafta; Erzurum Kongresi'nin yapılış amacı hakkında bilgi vererek, Paşa'yı kongreye katılmak üzere Erzurum'a davet etti ${ }^{6}$. Mustafa Kemal Paşa, Karabekir Paşa'nın davetine kabul ederek, kongreye katılmaya karar verdi. Bu amaçla 3 Temmuzda Erzurum'a geldi. 23 Temmuzda açılan kongrenin önce başkanlığına ve arkasından da kongrede alınan kararları hayata geçirmek için meydana getirilen Heyet-i Temsiliye'nin başkanlığına seçildi'. Mustafa Kemal Paşa ve Rauf Bey kongreye delege olarak katılmasıydı kararların bölgesel olacağına şüphe yoktu ${ }^{8}$. Fakat Erzurum kongresi kararları itibariyle olmasa da, delegeleriyle itibariyle bir bölgesel kongre idi. Bu sebeple daha geniş katılımlı bir kongreye; Sivas Kongresi'ne ihtiyaç vardı.

Mustafa Kemal Paşa, Erzurum Kongresi'nin bitimiyle birlikte yeniden Sivas Kongresi'nin hazırlıklarıyla ilgilenmeye başladı. Zira Erzurum Kongresi, Doğu Anadolu ve Doğu Karadeniz'e yönelik Ermeni ve Rum tehdidini bertaraf etmek üzere yapılmış, bölgesel bir kongre idi. Ama ülkenin karşı karşıya kaldığı sorunlar sadece Rum ve Ermeni tehdidinden kaynaklanmıyordu. Batı Anadolu'da Yunanlılar, Güney Anadolu'da İtalyanlar, Güneydoğu bölgesinde Fransız-Ermeni ittifakı Türk Milleti'ne hayat hakkı tanımak niyetinde değillerdi. Elviye-i Selâse ve Samsun'daki İngiliz işgali de gözden uzak tutulmamalıydı. Bu sebeple Mustafa Kemal Paşa, Sivas'ta yapılacak kongreyle Erzurum'da alınan kararları ülkenin her köşesinden gelen delegelerle tartışarak ve bütün ülkeyi kapsayacak şekilde genişletmeyi milletin kurtuluşu açısından son derece önemli görmekteydi.

Sivas Kongresi, Erzurum'un aksine daha açılmadan önce bir takım sorunlarla karşılaştı. Bunlardan bir kısmı delegelerden, diğer kısmı ise İstanbul Hükümeti'nin kongrelere ve özellikle milli bir kongre olacağı çok önceden bütün kamuoyuna duyurulmuş olan Sivas Kongresi'ne karşı takındığı düşmanca tavırdı.

Kongre öncesinde Vilâyât-1 Şarkiyye Müdafaa-i Hukuk-1 Milliye Cemiyeti içinden ve hatta Heyet-i Temsiliye üyelerinden bazıları, Erzurum Kongresi kararlarını kendileri için yeterli görerek, Sivas Kongresi'ne gerek olmadığını düşünüyorlardı. Onlara göre önemli olan bölgenin kurtarılmasıydı. Mustafa Kemal Paşa'ya göre ise, ülkenin kaderi top yekün ele alınmazsa bölgesel çareler de gün gelip yok olabilirdi. Mustafa Kemal Paşa'nın karşılaştığı bir diğer sorun da mülkî amirlerin İtilaf Devletleri temsilcilerinin ve hatta İstanbul Hükümeti'nin tehditlerini dikkate alarak, kongrenin Sivas'ta yapılmaması hususunda gösterdikleri zayıflıktı. Her iki

${ }^{6}$ Kâzım Karabekir, İstiklal Harbimiz, I, İstanbul 1993, s.85.

${ }^{7}$ Heyet-i Temsiliye'nin oluşturulması hakkında geniş bilgi için bkz: Dursun Ali Akbulut, "Heyet-i Temsiliye Nasıl Teşekkül Etti”, Atatürk Ǘniversitesi, Atatürk İlkeleri ve İnkılâp Tarihi Enstitüsü Dergisi, Sayı: I/4 (Erzurum 1990), s.44-56.

${ }^{8}$ Ali Fuat Cebesoy, Milî Mücadele Hatıraları, İstanbul 1953, s.123. 
sorunda Mustafa Kemal Paşa'nın engin liderlik ve ileri görüşlülüğü sayesinde kısa sürede aşıldı ${ }^{9}$.

Sorunların en büyüğü İstanbul Hükümeti'nin kongre aleyhindeki politikalardan kaynaklanıyordu. Damat Ferit Hükümeti, kongreler yoluyla her geçen gün gelişmekte olan ve halkın büyük kıymet vermeye başladığı Milli Mücadele'yi isyan, onun başındaki büyük isim Mustafa Kemal Paşa'yı da asi göstermek için her türlü girişimin içerisinde yer aldı. Mustafa Kemal Paşa'nın askerlikten istifasını fırsat bilerek, onu tutuklatmak için 15. Kolordu Komutanı Kâzım Karabekir Paşa nezdinde girişimlerde bulunulmuştu. Fakat Karabekir Paşa buna sıcak bakmadığı gibi, bu yöndeki girişimlere de şiddetli tepki gösterdi ${ }^{10}$.

Damat Ferit Paşa ve onun en büyük destekçisi Dahiliye Nazırı Adil Bey, Mustafa Kemal Paşa'yı tutuklatmak ve böylece Milli Mücadele'yi ortadan kaldırmak sevdasından vazgeçmedi. Elazığ Valisi Ali Seydi Bey'in görevden alınarak, yerine maceracı, dar görüşlü ve şahsi çıkarlarını ön planda tutan bir kişiliğe sahip Ali Galip'in tayin edilmesi bu düşüncenin bir tezahürüydü. Ali Galip, Elazığ'a giderken Sivas'ta kaldığı günleri Mustafa Kemal Paşa'nın tutuklanması için Sivas Valisi Reşit Paşa'yı kazanmakla ve hatta bazen baskı yapmakla geçirdi. Ama başarılı olamadı. Üstelik 27 Haziran 1919'da Sivas'a gelen Mustafa Kemal Paşa'nın hiddetine maruz kalınca, daha fazla beklemeyerek Elazı ğ'a hareket etti ${ }^{11}$.

Dahiliye Nazırı Adil Bey, Mustafa Kemal Paşa'yı tutuklamaya yönelik çabalarının başarısızlıkla sonuçlanmasının yanı sıra, Sivas Kongresi'nin hazırlıklarının süratle tamamlandığını haber alınca, Sivas Vilayeti'nden kongrenin engellenmesini istedi. Lakin vatanperverliğiyle tanınan ve Ali

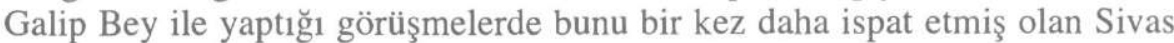
Valisi Reşit Paşa, isteği dikkate almadığı gibi, kongrenin yapılması için elinden gelen bütün gayreti de sarfetti ${ }^{12}$. Reşit Paşa aracılığıyla kongrenin yapılmasına engel olamayacağını anlayan Dahiliye Nazırı, kongreyi zorla

${ }^{9}$ Atatürk, Nutuk, I, s.77-81; Kemal Atatürk, Nutuk, III, İstanbul 1982, s.935-937; Cebesoy, Millî Mücadele Hatıraları, s.124.

${ }^{10}$ Harp Tarihi Vesikaları Dergisi, Sayı:3 (Mart 1953), Belge No:58; Karabekir, İstiklal Harbimiz, I, s.132-133.

${ }^{11}$ Kamil Erdeha, Milli Mücadelede Vilâyetler ve Valiler, İstanbul 1975, s.120-121; Kemal Ariburnu, Sivas Kongresi, Ankara 1997, s.133.

${ }^{12}$ Kongrenin engellenmesi ve Mustafa Kemal Paşa'nın tutuklanması hususunda hükümetin ne tür gerekçeler ileri sürdüğünü göstermesi açısından Dahiliye Nazırı Adil Bey'in Sivas Valiliği'ne gönderdiği bir telgrafı yer vermek faydalı olacaktır: "Sivas Vilâyetine, Mustafa Kemal ve Rauf Beylerin (!) hükûmetin tebligatına muhalif tahrik ve teşviklerde devam etmekte oldukları imzaları altında neşretmekte oldukları beyannamelerle vukubulan iş'ardan anlaşılmış olmasına binaen hemen derdest edilerek Dersaadet'e izamları Meclisi Vükelâ kararile tebliğ olunur. Harbiye nezaretinden de Kolordu Kumandanlarma tebligat ifa olunmuştur. 29 Temmuz 335. Dahiliye Nazırı Adil" (Cevdet R. Yularkıran, Reşit Paşanın Hatıraları, İstanbul 1939, s.77). 
dağıtmaya, bu iş için de önceki başarısızlığına rağmen Elazığ Valisi Ali Galip'i kullanmaya karar verdi ${ }^{13}$. Ali Galip'in Milli Mücadele karşıtı olması kadar, 27 Haziran 1919'da Mustafa Kemal Paşa'dan ağır laflar duymasının da görevi kabul etmesinde etkili olabileceği gözden uzak tutulmamalıdır ${ }^{14}$. Yapılan plana göre, Ali Galip, Bedirhanilere mensup kişilerin aracılığı ve desteğiyle para karşılığında 150-200 kișilik bir silahlı grup meydana getirecek,daha sonra bu kuvvetle Sivas'a yürüyerek Mustafa Kemal Paşa ve dava arkadaşlarını tutuklayacaktı ${ }^{15}$.

Ali Galip ve arkadaşlarının hazırlıkları Mustafa Kemal Paşa tarafından yakından izlenmekteydi. Mustafa Kemal Paşa, Ali Galip Bey'in Malatya'ya geçmesi üzerine şer hareketini yok etmeye karar verdi. Bu amaçla 3 . Kolordu Komutanı Selahattin Bey aracılığıyla 13. Kolordu kurmay başkanına 7 Eylül 1919'da verdiği emirde; Ali Galip Bey, Malatya Mutasarrıfı Halil, Bedirhanilerden Kamûran, Celâdet, ve Ekrem Beyler ile İngiliz Binbaşısı Noel'in yakalanarak Sivas'a gönderilmesini istedi. 13. Kolordu Kurmay Başkanı Halit Bey'in 7/8 Eylül gecesi verdiği cevaptan kolordunun harekete geçmekte gecikeceğinin anlaşılması üzerine, Mustafa Kemal Paşa 15. Alay Komutanı Binbaşı İlyas Bey’den Ali Galip Sorunu'nu bizzat halletmesini istedi. Aynı gece Malatya'da bulunan 12. Süvari Alay Komutanı Cemal Bey'le de görüşerek, Ali Galip ve yandaşları hakkında bilgi aldıktan sonra, İlyas Bey'e verdiği emri ona da tekrar etti ${ }^{16}$. İlyas Bey, aldığı emir doğrultusunda harekete geçerek, 10 Eylülde Malatya'ya girdi. Mustafa Kemal Paşa'ya gönderdiği telgrafta; Ali Galip ve yandaşlarının Kahta yönünde kaçtıklarını, yakalanmaları için çalıştığını haber verdi ${ }^{17}$.

Ali Galip Sorunu'nun askerî cephesinin bu şekilde halledilmesine karşın, siyasî cephede verilecek mücadele daha yeni başlamaktaydı. Zira büyük komutan Milli Mücadele'nin ortadan kaldırılması için sahnelenmek istenen oyunu, eşsiz dehasıyla Milli Mücadele'nin kuvvetlendirilmesi için İstanbul Hükümeti aleyhine kullanmaya karar verdi. Bu yönde birbiriyle ilişkili bir çok hedef gözetti. Bunların başında halkın Milli Mücadele Hareketi'ne kazandırılması gelmekteydi. İkinci hedef ordunun kazanılmasıydı. Üçüncü ve en büyük hedef ise milletin ve ordunun desteğini arkasına alan Heyet-i Temsiliye'nin merkezi hükümeti değiştirerek, kendi

${ }^{13}$ Dahiliye Nazırı ile Ali Galip arasında yapılan görüşmeler hakkında geniş bilgi için bkz: Erdeha, Milli Mücadelede Vilâyetler ve Valiler, s.126-134; Arıburnu, Sivas Kongresi, s.145-149.

${ }^{14}$ Ali Galip Bey'in, Mustafa Kemal Paşa ve Milli Mücadele hakkındaki düşüncelerini Sivas Valisi Reşit Paşa'nın hatıratında bulmak mümkündür. Reşit Paşa'ya göre; Ali Galip Bey, Mustafa Kemal Paşa'nın devlet aleyhine isyan hazırladığına inanmakta ve bunun önlenebilmesi için Paşa'nın kesinlikle tutuklanması gerektiğini düşünmekteydi (Yularkıran, Reşit Paşanın Hatıraları, s.44)

${ }^{15}$ Atatürk, Nutuk, I, s.116; Yunus Nadi, Ali Galip Hâdisesi, İstanbul 2000, s.35.

${ }^{16}$ Atatürk, Nutuk, I, s.120-121.

${ }^{17}$ Atatürk, Nutuk, I, s.123. 
ilke ve programıyla uyumlu bir hükümeti iktidara getirmesiydi. Bunun başarılması durumunda Heyet-i Temsiliye ülke genelinde son derece önemli bir siyasî güç haline gelmiş olacaktı.

Tabii bu hedeflere ulaşmak için öncelikli olarak ciddi bir kamuoyu desteğine ihtiyaç vardı. Bu noktada Milli Mücadele'yi canı gönülden destekleyen iki büyük gazeteye; İrade-i Milliye ve Albayrak'a önemli görevler düşmekteydi. Yapılan diğer çalışmaların yanında, gazetelerde yaklaşık iki hafta boyunca gerek Ali Galip-Hükümet ilişkisini ortaya koyan resmi belgelerin, gerekse olayın milli birliğe ve ülke bütünlüğüne verdiği zararları konu edinen makalelerin yayınlanması kamuoyunun kazanılmasında son derece etkili oldu. Mustafa Kemal Paşa'nın direktifleri sayesinde şekillendirilen yayınların sonucunda Milli Mücadele lehinde kazanılan kamuoyu, yine onun tarafından İstanbul Hükümeti üzerinde siyasî baskı kurması için yönlendirildi. Bu sayede Damat Ferit Paşa'nın iktidardan uzaklaştırılması sağlandı.

Kamuoyunun tam olarak Milli Mücadele çizgisine getirilmesi bir anda olmadı. Yayınlarda öncelikli olarak, merkezi hükümetin anayasayı çiğnediği teması işlendi. Hükümet, kanunlar çerçevesinde kurulan bir cemiyeti ve yine onun kanunlar çerçevesinde gerçekleştirdiği kongreyi kanunsuz yollarla engellemeye çalışmakla suçlandı. Bunun ötesinde vatandaşların maruz kaldıkları haksızlığı Padişaha anlatma isteğinin engellenmesiyle hükümetin anayasal bir hakka; haberleşme hakkına tecavüz ettiği vurgulandı. Bu hususları ön plana çıkaran yayınlar sayesinde insanların zihninde kanunları hiçe sayan ve vatandaşlarına büyük haksızlıkları reva gören ve hatta onların arasındaki etnik farklılıkları kendi çıkarına alet eden bir hükümet portresi oluşturuldu. Sonraki adım yukarıda ifade edilen fiilleri işleyen hükümetin meşru olup olmadığını tartışmaya açmak oldu. Bu kadar suçu olan bir hükümetin halka, orduya ve basına rağmen iktidarda kalabileceğini düşünmek mümkün değildi. İşte bu noktada Mustafa Kemal Paşa, Mebusan Meclisi'nin açılarak bir milli hükümetin işbaşına getirilmesi isteğini ortaya atarak nihai hedefi ortaya koydu. Türk kamuoyunun çok kısa sürede Heyet-i Temsiliye lehine çevrilmiş olmasından dolayı, bundan birkaç ay önce bu fikri tartışmak bile istemeyen kesimler milli hükümet kurulmasını öngören teklifi büyük bir istekle ve içtenlikle desteklemeye başladılar ${ }^{18}$. Bu sayede başını Mustafa Kemal Paşa'nın çektiği meşrutiyetçiler, mutlakıyetçiler karşısında önemli siyasî bir başarı elde etmiş oldular ${ }^{19}$.

Yapılan yayınların milli birliği kuvvetlendirmeye önemli katkılar sağladığı da gözden uzak tutulmamalıdır. Zira Ali Galip Bey'in Kürtleri kullanmak istemesi Kürt aşiret reislerinin gazetelere gönderdikleri telgraflarla protesto edildi. Telgraflarda Kürtlerin devletin ve milletin birliği noktasında Türklerle hemfikir oldukları belirtildi.

\footnotetext{
${ }^{18}$ Yularkıran, Reşit Paşanın Hatıraları, s.150.

${ }^{19}$ Erdeha, Milli Mücadelede Vilâyetler ve Valiler, s.137.
} 
Ana hatlarıyla tanımlanmaya çalışılan ve her safhası Mustafa Kemal Paşa tarafından büyük bir titizlikle hazırlanan stratejinin İrade-i Milliye ve Albayrak'ta ne tarzda ele alındı̆̆ına değinmekte yarar vardır.

Yukarıda izah edilmeye çalışıldığı gibi gazetelerde öncelikle merkezi hükümete hiçbir şekilde güvenilmediği hususu işlenmeye başlandı. Bunun için de Mustafa Kemal Paşa'nın verdiği direktif doğrultusunda mülkî makamların Dahiliye Nazırı Adil Bey'e, komutanların da Harbiye Nazırı Süleyman Şefik Paşa'ya hitaben yazdıkları telgraflara yer verildi ${ }^{20}$. Telgraflarda nazırların Ali Galip Beyi kongreyi basmaya teşvik eden yazılarına yer verilerek, bunun kanunlar karşısında suç teşkil ettiği vurgulandı. İrade-i Milliye'nin 14 Eylül 1919 tarihli nüshasında Sivas Valisi Reşit Paşa'nın Adil Beyi suçlayan telgrafı bunun ilk örneğini teşkil etmektedir. Reşit Paşa telgrafında özetle şu hususlara değinmekteydi:

"Zât-ı alileriyle Ali Galip Bey arasında teati olunan telgraflar kongre heyetince elde edilmiştir. Verdiğiniz emir ve Galip Bey'in yerine getirmeye çalıştı̆̆ görev hayretime sebep oldu. Müslümanları birbirine kırdırmak için cinayet tertipliyorsunuz. Burada Padişaha isyan etmiş bir kitle mi var ki, eşkıyadan meydana gelen bir kuvvet göndermeye ihtiyaç görüyorsunuz? Önceden ve sonradan arz ettiğim gibi vilayet içinde asayişi bozan en küçük bir hareket yoktur. Sirf Mustafa Kemal Paşa ile Rauf Beyi yakalamak ve kongreyi dă̆ıtmak için memleketi ateşe verip büsbütün elden çıkarmaya sebep olmak vatan ve millete karşı ihanet değil midir? Zat-l aliniz hırsınız yüzünden gerçeği göremiyor ve gerçekleri söyleyenleri sevmiyorsunuz. Onları susturmak, ezmek istiyorsunuz ve bilerek bilmeyerek düşmanların ekmeğine yağ sürüyor, memleketi felakete sürüklüyorsunuz,"21.

Gazetenin aynı nüshasında Ali Galip Bey ile Dahiliye Nazırı Adil Bey arasında yapılan yazışmalar "Vesika-i İhanet" başlı̆̆ıyla kamuoyuna duyuruluyordu. Gazetede yer alan bir makalede ise, Ali Galip Bey'in Reşit Paşa'nın yerine Sivas Valiliğine atandığına dair Padişahın iradesi alınmamasına rağmen Sivas Vilayeti’ne gönderilen yazıda iradenin alınmış gibi gösterilmesi de eleştirilerek, Dahiliye ve Harbiye nazırları Padişahın adını kullanarak sahte irade-i seniye uydurmakla ve komplolarına padişahı da alet etmekle suçlanıyorlardı.

Gazetenin aynı nüshasında Mustafa Kemal Paşa imzasıyla yayınlanan bir telgrafa yer verilmekteydi. Mustafa Kemal Paşa, milletin padişahı durumdan haberdar etme girişiminin hükümetçe engellenmesine muhalefet ederek, kabineyi devlet ve millet aleyhine hain oyunlar çevirmekle itham ediyordu ${ }^{22}$.

\footnotetext{
${ }^{20}$ Atatürk, Nutuk, I, s.131.

${ }^{21}$ İrade-i Milliye, 14 Eylül 1335/1919, Nr:1; Yularkıran, Reşit Paşanın Hatıraları, s.142-143.

${ }^{22}$ İrade-i Milliye, 14 Eylül 1335/1919, Nr:1.
} 
İrade-i Milliye'nin 17 Eylülde çıkarılan ikinci sayısında Ali Galip olayı ele alınmaya devam edilmekteydi. Bir makalede Adil Bey açıça devlete ihanet etmekle suçlanıyordu. Adil Bey'in Reşit Paşa'nın telgrafına verdiği cevaptan alınan bazı pasajlarda kelime oyununa gidilerek, Adil Bey'in devletin hizmetkârı olduğunu iddia eden ifadesi doğru bulunmayarak, kendisinin "Hedm" kökünden türetilen ve devleti milleti yıkan kişi anlamına gelen "Hâdim-i devlet ve millet" olduğu öne sürülmekteydi. Reşit Paşa'nın Adil Bey'e gönderdiği ikinci telgrafta; Reşit Paşa, görevden alınmış olduğuna dair eğer gerçekten bir irade-i seniye çıkarılmış ise bunun "güvenilir bir nazır" tarafından kendisine ulaştırılmasını istiyordu. Paşa dolaylı biçimde Adil Bey'in yalancı olduğunu gazete okurlarına duyurmaktadır ki, bir nazırın emrindeki validen bu şekilde hakaret görmesi gerek mülkî idare, gerekse kamuoyu nezdinde hükümetin düştüğü hali gözler önüne sermektedir. Gazetede kongreye karşı tertiplenen komplonun bir ayağını oluşturan İngiliz Binbaşısı Noel en az Ali Galip Bey ve arkadaşları kadar suçlanmaktaydı. Noel'in, İstanbul'daki İngiliz Yüksek Komiserliği'ne gönderdiği telgrafta; Sivas kongresini basmak için Ali Galip Bey'e yardımcı olan Bedirhaniler ve Cemil Paşazâde ailesinden Ekrem ile Makareli Rahmi Beylerin can güvenliklerinin sağlanmasını istemesi kamuoyunun takdirine birakılıyordu ${ }^{23}$.

17 Eylülde çıkan son iki yazının ilki Umumi Kongre Heyeti imzasıyla yayınlanmış olup, “Malatya Vak'ası Üzerine Millete Neşredilen Beyanname” adını taşımaktaydı. Beyannamede; Teşkilat-1 Milliye'nin varoluş amacı üzerinde durularak, teşkilatın ve kongrenin kendi başının çaresine bakmak zorunda bırakılan milletin iradesinden doğduğu, buna karşın hükümetin devleti yıkmak isteyenlerle beraber hareket ettiği ve hatta Galip Bey gibi insanları kullanarak milletin ve vatanın parçalanmasına yol açabilecek oyunların içinde yer aldığı belirtiliyordu.

Gazetede çıkan son yazı Ali Galip Bey'in Malatya'daki çalışmalarını içeren rapordu. 10 Eylül tarihli raporda özetle şu hususlar belirtilmekteydi. Ali Galip Bey, Malatya'ya geldiğinde askerî kışlayı ziyaret etti. Askerlere kongrenin İttihatçı olduğunu, vatanı tehlikeye sürüklediği ifade etmekle kalmayarak Mustafa Kemal Paşa hakkında da olumsuz beyanda bulundu. Subaylar olumsuz propagandaya itibar göstermediler. Ali Galip Bey, hükümetten aldığı emir doğrultusunda hareket etmeye çalışırken kendisine eşlik eden Malatya Mutasarrıfı doğrudan doğruya Kürtçülük propagandası yapmaktayd ${ }^{24}$.

İrade-i Milliye'nin 21 Eylül tarihli nüshasında ise çıkan haberler iki husus üzerinde yoğunlaşmaktaydı. Bunlardan ilki, Bedirhaniler, Cemil Paşazâdeliler ve İngiliz Binbaşısı Noel'in Ali Galip olayından faydalanarak bir Kürt isyanı çıkarmaya çalıştıklarıydı. Diğeri ise, bu ayrılıkçı hareketin

\footnotetext{
${ }^{23}$ İrade-i Milliye, 17 Eylül 1335/1919, Nr:2.

${ }^{24}$ İrade-i Milliye, 17 Eylül 1335/1919, Nr:2.
} 
gerçekte Kürtler tarafından desteklenmediği, aksine şiddetle protesto edildiğiydi. Bu noktada Kürt aşiretleri tarafından gönderilen telgraflara yer verilmekteydi. Malatya muhabiri tarafından kaleme alınan "Malatya Hadisesi Üzerine Tetkikat" adını taşıyan haberde muhabir, Ali Galip, Binbaşı Noel ve ayrılıkçı Kürtlerin Urfa'ya kaçtıklarını, fakat bu kişilerin farkl1 amaçlar takip ettiklerini, bu sebeple ortak hareket etmekte anlaşamadıklarını, buna karşın Malatya Mutasarrıfının bir Kürt ayaklanması çıkarmak için yoğun gayret içerisinde olduğunu, bu amaçla Bedirhaniler ve Noel ile birlikte Milli Aşireti reisini kazanmaya çalıştı̆̆ını haber vermekteydi. Bütün bu millet ve devlet aleyhindeki çalışmalara Malatya ahalisinin asla sıcak bakmadığı, aksine ülkenin içinde bulunduğu şartlar sebebiyle güçlü ve namuslu bir milli hükümetin işbaşına getirilmesini istediği yazıda özellikle vurgulanmaktaydı. Bu tespit de göstermektedir ki, Ali Galip ve yandaşlarının kongreyi basmak için umutlarını bağladıkları Malatya ahalisi dahi onlara cephe almıştır.

Ali Galip Olayı'nın su yüzüne çıktığı ilk günden itibaren kongreyi basma girişiminin bir Kürt-Türk çatışmasına dönüştürülmesinden ciddi şekilde endişe edilmekteydi. İrade-i Milliye'de çıkan haber ve yorumlar bu endişe göz önünde tutularak, milli birliğin korunması gerektiği noktasında birleşiyordu. Binbaşı Noel ve işbirlikçilerinin gayretlerine rağmen, sağduyunun hakim olduğu ve vatanın asli unsuru olan Kürtlerin bu gibi çalışmalara asla itibar etmedikleri gönderdikleri telgraflardan ortaya çıkmaktaydı. Gazetenin 21 Eylül tarihli nüshasında iki telgrafa yer veriliyordu. Birinci telgraf, Eleşkirt Aşiretleri reislerinden Ali Beyzâde Aziz ve Mustafa Nuri (Bitlisi) Beyler tarafından gönderilmişti. Telgrafta; Bedirhanilerin İngiliz parası ve yardımıyla yaymaya çalıştıkları haber ve sözlerin yalan olduğunun ortaya çıkmasından duyulan memnuniyet dile getirilerek, Kongre heyetinin yaptığı çalışmaların şükran ve minnetle anıldığı ifade edilmekteydi. Bunun dişında ülkenin kurtuluşu için Kürtlerin hayatlarını feda etmeye hazır oldukları vurgulanıyordu.

İkinci telgraf, gönderilen yer itibariyle öncekine oranla çok daha anlamlıydı. Zira Ali Galip olayının patlak verdiği andan itibaren Dersimli Kürtlerin olayın içerisinde olduğu, Malatya Mutasarrıfı'nın emriyle Malatya'da katliamlar yapacakları iddia edilmekteydi. Dersim aşiretleri adına Bahtiyar Aşireti reislerinden M. Sadri Bey, 18 Eylülde gazeteye gönderdiği telgrafında kendileri hakkında çıkartılan iddiaları şu sözlerle reddetmekteydi:

"Elâziz Valisi Ali Galib Bey'in Dersim'e gelerek, dersim aşairini $i g ̆ f a l$ ve selâmet-i vatan uğrunda bizeval mesai sarf eden muhterem kongre erkân-ı kıymetdarını tevkif için çalıştı̆̆ı ve Dersimliler'in de kendisine müzaharette bulunduğu haberi şayi oldu.

"Haşa... 
"Altryüz küsür seneden beri millet ve hükûmete her surette itaat ve hürmet- $i$ vatan-l mukaddeseye büyük bir muhabbetle merbut bulunan biz Dersimliler bu gibi zât-l firarileri kabul eden bir fitratda değiliz ve olamayız.

"Binaenaleyh firari Ali Galib Bey'in şu suretle Kürd millet-i necibesine, ezcümle Dersimliler üzerine sürdü̆̈̈̈ leke ve isnadl biz Dersimliler bütün mevcudiyetimizle protesto eder ve selâmet-i vatan uğrunda çalışan kongre erkân-ı muhteremesini takdir ve tebrik eyler ve her suretle sizlere itimad ettiğimizi ve elyevm mevki-i iktidarda bulunan Ferid Paşa kabinesi necibinin bu arzularının mevki-i adem-i itimadımız olduğunu Hilafet-i Uzmaya bildirilmesini istirham eyler, bu vesile ile muhterem ellerinizden öperim efendim.18 Eylül 335"25.

Görülüyor ki, aleyhlerinde çeşitli yalanlar ortaya atılan Kürt aşiretleri Ali Galip Olayına adlarının karışmasından rahatsızlık duymakta, gönderdikleri telgraflarla haklarında çıkartılan iddiaları yalanladıkları gibi, milletin asli parçası olarak kalmak azminde ve kurtuluş yolunda her türlü fedakarlığı yapmaya hazır olduklarını kamuoyuna duyurmaktaydılar.

Kamuoyu oluşturma ve Milli Mücadele Hareketi lehinde yönlendirme çalışmalarına komutanlar da büyük katkılar sağlamışlardır. Bu yönde İrade-i Milliye'de çıkan ilk yazı 3. Kolordu Komutanı Selahattin Bey'in Harbiye Nezareti'ne gönderdiği telgraftır. Selahattin Bey telgrafında şu hususlara yer vermekteydi: Harbiye Nezareti sebepsiz yere Kolorduyu kandırmaya çalışmıştır. Azlim hakkında bir irade-i seniye çıkarılmadan nezaretçe böyle bir irade varmış gibi işlem yapılmak istenmesi açıkça Padişahın hukukuna saldırılması anlamına gelmektedir. Kolordu bütün imkanları seferber ederek asayişin korunmasına gayret gösterirken, Nezaretin bir takım şahsi çıkar peşinde koşan insanlarla işbirliği içerisinde olması kabul edilemez. Kolorduya ve dolayısıyla bütün orduya güvensizlik duyulması hayretle karşılanmıştır. Kolordunun ve mülkî idarenin şimdiye kadar gerçekleştirdiği övgüye değer hizmetlerin göz ardı edilerek adi yollara başvurulması ve hıyanet tertip edilmesi üzerine, Padişahın olaylardan haberdar edilmesi bir zorunluluk haline almıştır ${ }^{26}$.

Bu sözlerden hükümetin ve ilgili nazırların kongreyle ilgili olarak dile getirdikleri iddiaların gerçekleri yansıtmadığı, üstelik hükümetin bizzat içinde yer aldığı adi bir komployla mevcut asayiş ve düzeni bozmak isteği sonucu ortaya çıkmaktadır.

Selahattin Bey'in telgrafından dört gün sonra (21 Eylülde) biri 20. Kolordu Komutan Vekili Ömer Halis ve Kurmay Başkanı Mahmut Beylerin ortaklaşa imzaladıkları, diğeri 15. Kolordu Komutanı Karabekir Paşa, 13. Kolordu Komutanı Ahmet Cevdet Bey, 11. Tümen Komutanı Mümtaz Bey

\footnotetext{
${ }^{25}$ İrade-i Milliye, 21 Eylül 1335/1919, Nr:3.

${ }^{26}$ İrade-i Milliye, 17 Eylül 1335/1919, Nr:2.
} 
ve 3. Kolordu Komutanı Selahattin Beyler tarafından imzalanarak Sadarete gönderilen ortak telgraf İrade-i Milliye'de yer aldı. Komutanlar, hükümeti kanun dişı tertiplerin içerisinde yer alarak ülkenin asayişini bozmakla suçlamaktaydılar. Ayrıca Kürtlerin kışkırtılarak milli birliğe zarar verilmek istenmesine karşın alınan etkili asker̂̂ önlemler sayesinde ülkenin ve milletin bu tehlikeden kurtarıldığı ifade edilerek, durumun Padişaha arz edilmek istendiği belirtilmekteydi ${ }^{27}$.

Telgraflarda bir hususun önemle altı çizilmiştir. O da, ülke sorunlarının çözümünde ordunun milletle beraber hareket edeceğinin vurgulanmasıydı. $\mathrm{Bu}$ da ordunun Milli Mücadele lehinde kazanıldı ğını ve Heyet-i TemsiliyeHükümet mücadelesinde Heyet-i Temsiliye'nin yanında yer alacağını göstermektedir.

Yapılan yayınlar sayesinde Milli Mücadele'nin tek kurtuluş yolu olduğunu anlayan millet, Heyet-i Temsiliye ile kader birliği yapmaya karar vermişti. İstanbul-Anadolu ilişkilerinin koparılması esnasında Heyet-i Temsiliye'den yana tavır alması bunun en açık ispatıdır. Ülkenin her köşesinden gönderilen destek telgrafları Mustafa Kemal Paşa'nın amacına ulaştığını ispatlıyordu.

17 Eylülde Ankara'dan Bidayet Müdde-i Umumisi Halil Bey başkanlığındaki 9 üst düzey mülkî memur Milli Kongrenin ile ahalinin gönderdikleri ve hükümete güvenmediklerine ilişkin telgrafın içeriğini kabul ettikleri ifade ediyorlardı. Aynı günkü nüshada Erzincan ahalisi adına Belediye başkanı Halil Bey tarafından bir telgrafa daha yer veriliyordu. Halil Bey, bütün Erzincanlıların Padişahtan milletin güvenine layık bir hükümeti işbaşına getirilmesini istediklerini beyan ediyordu ${ }^{28}$.

İrade-i Milliye'nin 21 Eylül tarihli nüshasında Kemah'tan Kaymakam Talat, Belediye Başkanı Dursun ve Müftü Şükrü Efendi ile 8 önemli mülkî memurun imzalayarak Sadaret'e gönderdikleri telgrafa yer veriliyordu. İmza sahipleri, hükümeti Padişahın şeref ve haysiyetini zedeleyen girișimlerde bulunmakla suçlayarak, milletin padişahtan başkasına güveni kalmadığını, su yüzüne çıkan kanunsuzluklara devam edilmesi halinde milletin artık kendisini hareket ve icraatında serbest kabul edeceğini ilan ediyorlardı. Kastamonu'dan da 29 önemli şahsın imzalayarak gönderdikleri telgrafta; Kastamonuluların hükümetle ilişkilerin koparılmasını canı gönülden destekledikleri ifade edilmekteydi ${ }^{29}$.

Heyet-i Temsiliye'yi destekleyen telgraflar bunlarla sınırlı kalmadı. 28 Eylül tarihli İrade-i Milliye'de; Sungurlu, Nallıhan, Çankırı, Şabanözü,

\footnotetext{
${ }^{27}$ İrade-i Milliye, 21 Eylül 1335/1919, Nr:3

${ }^{28}$ Irade-i Milliye, 17 Eylül 1335/1919, Nr:2.

${ }^{29}$ İrade-i Milliye, 21 Eylül 1335/1919, Nr:3.
} 
Akdağmadeni, Osmancık, Mecidözü, Van, Cide, Alaca, Yozgat, İskilip ve Çerkes'ten aynı içerikte gönderilen telgraflara yer veriliyordu ${ }^{30}$.

Telgrafları kaymakam, belediye başkanı, vali vekili, ulema ve tüccar sıfatlarına sahip insanların imzalamaları topyekün halkın Heyet-i Temsiliye'nin eylem ve kararlarını onayladıklarını gösteriyordu.

İrade-i Milliye, Heyet-i Temsiliye'yi destekleyen tek gazete değildi. 5 Mart 1919'da Erzurum'da yeniden yayın hayatına başlayan ve sorumlu müdürlügünü Süleyman Necati Bey'in yaptığı Albayrak gazetesi Vilâyât-1 Şarkiyye Müdafaa-i Hukuk-1 Milliye Cemiyeti Erzurum Şubesi'nin yayın

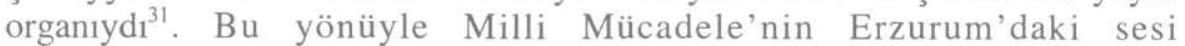
durumundaydı. Bu sebeple bölgede Milli Mücadele ve milli teşkilatlanmaya yönelik her girişim ve çalışmayı destekledi, canla başla savundu. Gazete Sivas Kongresi'ni Erzurum Kongresi'nin devamı olarak görmekte ve desteklemekteydi. Sivas Kongresi, Milli Mücadele yolunda atılmış büyük bir adım olarak kabul edilmekteydi. Gazetede kongreye ilișkin ilk yazı 4 Eylülde yayınland1. Yazıda kongre, "Vatanın maruz bulunduğu tehlike ve ihtiras karşısında milletin vicdanından doğan faaliyetlerin mahsullerinden biri" olarak nitelendiriliyordu. Aynı yazıda merkezi hükümetin kongreyi ve delegeleri yalan iddialarla millet nezdinde küçük düşürmesine tepki gösterilerek, milletin Kanun-1 Esasiye ve irade-i milliyeye önem vermeyen ve bu hususta ısrar eden hükümete karşı azim ve kararlılığını ortaya koymak için kongreyi yaptığını savunuyordu. Gazeteye göre, Mebusan Meclisi şimdiye kadar açılmış olsaydı, milletin bu yola başvurmasına gerek kalmayacakt $1^{32}$.

Ali Galip Olayı'nın patlak vermesinin ardından padişaha gönderilen telgrafların Dahiliye Nazırı Adil Bey'in emriyle engellenmesi 11 Eylülde “Hükümet Ne Yapmak İstiyor?" başlığıla çıkan makalede şiddetle eleştirildi. Makalede; hükümetin millet ile padişah arasına girmesine yetkisi olmadığı belirtilerek, eğer hükümet hareketinin meşruluğuna, ülkenin çıkarına uygunluğuna ve padişahın güvenine layık olduğuna inanıyorsa neden böyle bir eylemde bulunduğu soruluyordu. Bu hususlarda ciddi kuşkular var olacak ki, makalede hükümet ülke düşmanlarıyla birleşip milleti esir etmeye çalışmakla itham ediliyordu. Yazara göre, hükümet, milletin padişahla görüşmesine engel olmakla vatana ihanet etmiştir. Son olarak, hükümetin milleti sürü, irade-i milliyeyi bir hülya olarak görmesinin asla kabul edilmeyeceği vurgulanıyordu ${ }^{33}$.

${ }^{30}$ İrade-i Milliye, 28 Eylül 1335/1919, Nr:4.

${ }^{31}$ Albayrak gazetesi hakkında geniş bilgi için bkz: Dursun Ali Akbulut, Albayrak Olayı, Erzurum 1991; Süleyman Necati, Hatıra Defteri, (Yayına Hazırlayan: Ali Birinci) İstanbul 1999.

${ }^{32}$ Albayrak, 4 Eylül 1335/1919, Nr:25.

${ }^{33}$ Albayrak, 11 Eylül 1335/1919, Nr:26. 
Makaledeki hususlar alt alta getirildiğinde görülecektir ki, mevcut olaylar göz önünde tutularak hükümet önce anayasal hakları çiğneyen taraf olarak gösterilmekte, arkasından da bu tür kanunsuz eylemler planlayan hükümetin meşruluğunu kaybettiği tezi öne sürülmektedir. Sonuç olarak kamuoyuna hükümet vatana ihanet ettiği için iktidardan uzaklaştırılması gerektiği mesajı verilmektedir.

14 Eylülde "Millet Karşısında Hükümet -Hakimiyet Millete Aittir, Terk-i Ferağ Edilemez-" adıyla yayınlanan makalede, önceki makalede değinilen hususlara yer verilerek, özetle şu ifadeler sarf edilmekteydi:

Ortaya çıkan belgeler ışığında merkezi hükümet vatanın bütünlüğünü ve milletin bağımsızlığını tehlikeye düşürecek eylemlerin içinde bulunduğu ortaya çıkmıştır. Bir İngiliz binbaşısının büyük miktarda parayla Bedirhanilerden birkaç kişinin de millete karşı hazırlanan suikasta katılmaları ve bir Osmanlı valisi ile mutasarrıfin bu ihanete ortak olmaları sorunun mahiyetini ortaya koymaktadır. Bu haliyle Ferit Paşa Hükümeti meşruluğunu kaybetmiş, fakat her ne pahasına olursa olsun iktidarda kalmak isteyen zorba bir yönetimdir. Çünkü hükümet milletin güvenini kaybetmiştir ${ }^{34}$.

Görülüyor ki, hükümet sadece milletin anayasal haklarını çiğnememekte, iç ve dış düşmanlarla işbirliği yapmaktadır. Bu şartlarda iktidarda kalmasına imkan yoktur.

Hükümete karşı ileri sürülen bu tezler farklı kesimler tarafından gönderilen ve gazetede yayınlanan telgraflarla da desteklendi. Birincisi, Erzurum Ahalisi tarafından Padişaha, ikincisi ise Erzurum ve Van Valileri tarafından Sadarete gönderilmişti.

Erzurumlular tarafından gönderilen telgrafta kısaca şu hususlara değinilmekteydi: Dört buçuk asırdan beri Osmanlı Devleti'nin doğu sınırlarının korunmasını üstlenen ve büyük fedakârlıklarla bu görevi yerine getiren Erzurum ahalisi daima saltanat ve hilafete bağlı kalmıştır ve kalacaktır. Milli teşkilatları ülkenin parçalanmasına yol açacak siyasî cemiyetler, bunların savundukları fikirleri de yıkıcı akım gibi göstermeye çalışan hükümetin ülkede Türk-Kürt ikiliği doğurmaya çalışması ve bu amaçla teşkilat yapması, üstelik Elazı̆̆ Valisi ile görüşmeler yapması bizde güvensizliğin doğmasına yol açmıştır. Mevcut hükümetin yerine milletin güvenine layık bir kabine iş başına getirilmelidir.

Erzurum ve Van Valilerinin imzalarıyla yayınlanan telgrafta ise; Ali Galip Bey'in bir takım Kürtleri etrafına toplayarak Sivas'ı basmaya memur edilmesinin bölgede olumsuz etkiler yarattı̆̆ı, yürürlükteki kanunlar çerçevesinde meydana getirilen bir cemiyetin gerçekleştirdiği kongrede dile getirilen isteklere kayıtsız kalan hükümete karşı milletin ve ordunun

\footnotetext{
${ }^{34}$ Albayrak, 14 Eylül 1335/1919, Nr:27.
} 
güveninin kalmadığı, bu yüzden devletin ve milletin bütünlüğünü savunan bir idarenin derhal işbaşına getirilmesi talep edildi ${ }^{35}$.

Albayrak gazetesinin 18 Eylülde çıkan nüshasında üç telgraf yer aldı. Bunlar 15. Kolordu Komutanı Karabekir Paşa ve 13. Kolordu Komutanı Ahmet Cevdet Bey tarafından gönderilmiş olup, Hükümet ile Ali Galip Bey'in ortaklaşa hazırladıkları suikastı ve bunun yol açacağı tehlikeleri konu edinmişti.

Karabekir Paşa "Ihanet-i Malûme Üzerine 15. Kolordunun Beyannamesi" adıyla kaleme aldığı ilk yazısında hükümetin ihaneti konu edilmekteydi: Ferit Paşa kabinesi, Kürdistan kurulmasına taraftar olan bazı Kürt beyleriyle yakın ilişkiler kurmuştur. İşbirliğinin ardında iki hedef gözetilmektedir. Birinci Doğu Anadolu'yu isyan halinde göstererek, İtilaf işgaline zemin hazırlamak, ikinci ise Sivas'taki kongreyi basarak, milli hakları korumaktan öte bir amaç taşımayan milli hareketi yok etmektir. Böyle gayri meşru amaçlar için iki kardeş millet birbiri halinde kullanılmak istendi. Sivas'ın basılması halinde meydana gelecek çatışma Anadolu'nun işgaline meşruluk kazandıracaktı. Alınan askerî önlemler sayesinde ihanet planı uygulamaya sokulmadan engellendi. Hükümetin kesinleşen ihaneti her yerde nefret ve lanetle karşıland. Böyle bir zihniyete sahip hükümete milletin güveni kalmamıştır. Bu sebeple milletin güvenine layık, onun isteklerinden haberdar yeni yönetimin işbaşına getirilmesi gerek kongre heyetince, gerek bütün kolordularca, gerekse Erzurum ve Van Vilayetlerince istenmektedir.

Karabekir Paşa'nın ikinci yazısı gazete tarafından "15. Kolordu Kumandanı Tarafindan Makam-ı Sadarete Yazılan Telgraf Sureti” adiyla okuyuculara duyuruldu. Karabekir Paşa yazısında; kongrenin basılması halinde milli birliğin zarar göreceğinin farkında olan askerî makamların önceden aldığı önlemler sayesinde girişimin engellediğini, hükümetin sahnelemek istediği oyundan Padişahın haberdar edilmesi gerektiğini, bunun engellenmeye devam edilmesi halinde Damat Ferit Paşa'nın da bu hainlerle aynı grupta değerlendirileceğini belirtti.

13. Kolordu Komutanı Cevdet Bey tarafından gönderilen telgrafta ise, Ali Galip olayı öncesi ve sonrasıyla ayrıntılı bir şekilde anlatıldı. Cevdet Bey, girişimin bastırılması hususunda alınan askerî önlemlere kolordusunun büyük önem ve destek verdiğini belirttikten sonra, bölgesindeki bütün unsurların -13. Kolordu da dahil olmak üzere- Sivas Kongresi'nin kanuni olduğunu kabul ettiğini, suikastın arkasında Dahiliye Nazırı ile Harbiye Nazırının olduğunu, bu haliyle hükümete güvenilemeyeceğini, vatanı tehlikeye sokan kişilerin kanuna tesliminden başka çare olmadığını ifade

${ }^{35}$ Albayrak, 14 Eylül 1335/1919, Nr:27. 
ederek, kendisinin de bundan böyle Harbiye Nazırını amir olarak tanımayacağını ifade etti ${ }^{36}$.

21 Eylülde Padişaha hitaben yazılan bir makalede; Hükümet, İngiliz çıkarlarını korumanın dışında, Batı Anadolu'da Yunan işgaline ve hatta sınır düzenlemesiyle Batı Anadolu'nun Yunanistan'a bağlanmasına rıza göstermekle suçlanarak, bunun duyulması halinde kamuoyunun göstereceği tepkiden çekindiği için Sivas Kongresi'ni basma girişimini tezgahlayarak dikkatleri buraya toplamak istediği iddia edildi. Makaleye göre, hükümet Batı Anadolu'daki hezimetin duyulmasının iktidarına mal olacağını çok iyi bildiğinden, bir süre daha iktidarda kalabilmek için Sivas Kongresi'ni basma gibi vatanın ve milletin bütünlüğünü tehlikeye sokabilecek ihanetlere başvurmaktan çekinmemiştir ${ }^{37}$.

25 Eylülde Erzurum ahalisi tarafından Padişaha gönderilen telgrafta ise; hükümetin giriştiği eylemlerle milleti ve hilafet makamını iğfal ettiği, Doğu Anadolu'da asayişsizlik olduğu yalanını ortaya attığı, böylelikle İtilaf işgaline zemin hazırladığ 1 , bununla da yetinmeyerek milletin sinesinden doğan milli hareketi Bolşevik olmakla suçladı̆̆ı ifade edilerek, her uygulamasıyla milleti ve devleti uçuruma doğru sürükleyen hükümetin Kanun-1 Esasi gereği iktidardan uzaklaştırılması gerektiği ifade edildi ${ }^{38}$.

\section{SONUÇ}

Mustafa Kemal Paşa'yı tutuklamak ve Milli Mücadele Hareketi'ni ortadan kaldırmak amacıyla İstanbul Hükümeti'nin planladığı Ali Galip Olayı, Mustafa Kemal Paşa'nın eşsiz askerlik ve siyaset bilgisi sayesinde Milli Mücadele'nin zaferi haline dönüşmüştür.

Alınan askerî önlemler sayesinde bir yandan Sivas Kongresi'nin kapatılması tehlikesi bertaraf edilirken, diğer taraftan da İngilizlerin verdikleri maddi ve manevi destekten güç alarak İngiliz subayı Binbaşı Noel ile birlikte bölgede bir Kürt ayaklanması çıkarmak isteyen Bedirhaniler ve Cemilpaşazâdeliler ülke dışına kaçmak zorunda bırakıldılar.

Bu başarının ardından olay Mustafa Kemal Paşa tarafından ustalıkla ele alınarak, İstanbul Hükümeti'nin iktidardan uzaklaştırılması eylemine dönüştürüldü. Planın başarıya ulaşabilmesi için milletin ve ordunun desteğinin sağlanması gerekiyordu. Bunun içinde halkın doğru bilgilendirilmesi şarttı. Bu amaçla Milli Mücadele'nin sesi durumunda olan İrade-i Milliye ile Albayrak gazetelerinde yoğun bir şekilde haber, belge ve yoruma dayalı yazılar çıkarıldı. Mülkî ve askerî makamların imzalarıyla pek çok telgrafa yer verildi. Yazılarda hükümetin ne şekilde milletin haklarını çiğnediği ortaya konduğu gibi, iç ve diş düşmanlarla işbirliği yaptığı

\footnotetext{
${ }^{36}$ Albayrak, 18 Eylül 1335/1919, Nr:28.

${ }^{37}$ Albayrak, 21 Eylül 1335/1919, Nr:29.

${ }^{38}$ Albayrak, 25 Eylül 1335/1919, Nr:30.
} 
anlatılarak, hükümete karşı güçlü bir kamuoyu oluşturuldu. Kamuoyundan alınan destek sayesinde önce Anadolu'nun İstanbul ile ilişkilerini kestiği ilan edildi, arkasından hükümet istifaya zorlandı. Türk milleti Temsil Heyeti'nin dolayısıyla Mustafa Kemal Paşa'nın çizdiği yolda yürüyeceğini yine bu gazeteler aracılığıyla gerek İstanbul'a, gerekse dünyaya ilan etti. Bu azim ve irade karşısında daha fazla bir şey yapamayan Damat Ferit Hükümeti 1 Ekim 1919 'da istifa etmek zorunda kaldı. Yerine, Ali Rıza Paşa Hükümeti geçti. 